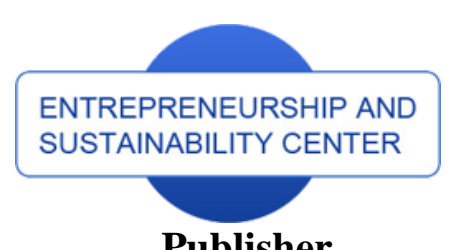

Publisher

http://jssidoi.org/esc/home enterprise

europe

network

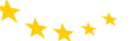

Business Support on Your Doorstep

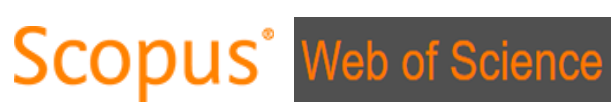

\title{
SECOND PENSION PILLAR PARTICIPANTS' BEHAVIOUR: THE LITHUANIAN CASE*
}

\author{
Teodoras Medaiskis $^{1}$, Tadas Gudaitis ${ }^{2}$, Jaroslav Mečkovski ${ }^{3}$ \\ ${ }^{1,3}$ Department of Quantitative Methods and Modelling, Faculty of Economics, Vilnius University, Sauletekio Al. 9, Vilnius, \\ Lithuania \\ ${ }^{2}$ Department of Business, Faculty of Economics, Vilnius University, Sauletekio Al. 9, Vilnius, Lithuania
}

E-mails: ${ }^{1}$ teodoras.medaiskis@evaf.vu.lt (corresponding author); ${ }^{2}$ tadas.gudaitis@vaef.vu.lt; ${ }^{3}$ jaroslav.meckovski@gmail.com

Received 15 March 2018; accepted 24 September 2018; published 30 December 2018

\begin{abstract}
Defined contribution pension pillars often require participants to take an active role in selecting pension funds during the whole accumulation period. It is expected that pension a fund participant will select an appropriate investment strategy and investment risk during the different stages of the accumulation phase and depending on the years left until retirement. In this paper, we have analysed the behaviour of second pillar pension fund participants in Lithuania from the establishment of the second pension pillar (2004) till Q3 of 2016. The aim of the study is to evaluate how rational second pension pillar participants were in decisions on selecting the accumulation rate, the appropriate pension fund (investment strategy and investment risk) and changing the pension fund over the accumulation period during various stages of the economic cycle in the financial markets. The results show that the majority of second pension pillar participants are irrational in selecting participation rates. Additionally, it was also observed that the majority of pension fund participants make irrational choices on selecting the pension fund (investment strategy and investment risk) and changing it over the accumulation period. The majority of pension fund participants have selected an inappropriate pension fund (investment strategy and investment risk) with regard to the accumulation period left till retirement. Moreover, participants are passive and tend not to change pension funds during the accumulation period. Pension fund participants who did change pension funds made irrational decisions and chose inappropriate pension funds (investment strategy and investment risk): in case of peak periods in stock markets, the majority of second pension pillar participants changed pension funds by switching from the funds with a lower proportion of equities to those with a higher proportion of equities or changed their pension fund to a fund in the same investment risk category. Moreover, in case of bottom periods in stock markets, the majority of participants did the opposite, switching from funds with a higher proportion of equities to those with a lower proportion of equities.
\end{abstract}

Keywords: Pension funds; Pension fund participants' choice; behaviour finance; life-cycle investment

Reference to this paper should be made as follows: Medaiskis, T.; Gudaitis, T.; Mečkovski, J. 2018. Second pension pillar participants' behaviour: the Lithuanian case, Entrepreneurship and Sustainability Issues 6(2): 620-635. http://doi.org/10.9770/jesi.2018.6.2(11)

JEL Classifications: J32, D14, D91

\footnotetext{
* This work was supported by the Research Council of Lithuania under Grant MIP-15204. The research has received funding from Research Council of Lithuania on research project agreement No MIP-012/2015
} 


\section{Introduction}

The fully funded second pillar pension was introduced in Lithuania on 1 January 2004 as a part of the reform of the pension system, which previously was based only on the pay-as-you-go principle.

The introduced second pension pillar is based on individual fully funded accounts of participants who are allowed to pay a part of their obligatory pension insurance contribution into their personal account, instead of paying the full contribution into the state social insurance fund. Due to this, the acquired old-age pension rights of the participants are proportionally reduced.

The second pillar is administrated by pension accumulation companies, which manage several pension funds with different investment strategies. Participation in the second pension pillar - unlike in many other countries with a similar system - is completely voluntary in Lithuania. By the end of 2016 Q3, more than 1.25 million participants - 96 per cent of those insured for a full pension - were accumulating capital in second pillar pension funds. The main principles of the pension reform in Lithuania are similar to those of many other post-communist countries (Latvia, Estonia, Poland etc.), where pension systems were reformed earlier (see Égert, 2012; Volskis, 2012).

In Lithuania, pension accumulation companies are offering pension funds with various investment strategies. They can offer a pension plan with up to 100 per cent of assets invested in equities. Each pension accumulation company is offering 3 to 6 pension funds. In Lithuania, pension funds are divided into four groups according to their investment strategy. This division should allow the monitoring, evaluation, and comparison of the investment results of second pillar pension funds with a similar investment risk. Most of the second pillar pension funds are "mixed": assets of second pillar pension funds are invested into high investment risk asset classes (e.g., equities) and into less risky asset classes (e.g., government bonds). The differentiation of investments according to high investment risk asset classes (equities) is the simplest way for classifying pension funds into different groups. According to the data of the Bank of Lithuania (2017), second pillar pension funds are divided into the following four groups depending on the share of investments into equities:

- conservative pension funds (assets under management (hereinafter, AUM) are not invested into equities);

- pension funds investing a small part of assets into equities (up to 30 per cent of AUM are invested into equities);

- pension funds investing a medium part of assets into equities (up to 70 per cent of AUM are invested into equities);

- pure equity pension funds (up to 100 per cent of AUM are invested into equities).

It is expected that a pension fund participant will be active and will change their pension fund strategy (risk) during the long-term pension accumulation period, and a life-cycle funds market does not exist.

In 2008-2009 global financial crisis significantly affected the second pillar pension too. On the one hand, the accumulated capital lost value due to turbulence in financial markets, on the other hand, fiscal deficit contributions to second pillar pension funds were decreased from $5.5 \%$ to $2 \%$ in 2009 . Later, the Lithuanian government decided to change participation the level (rules), and in 2013 the participants of second pillar pension funds had to choose their participation level (contributions level) by selecting one of the following options:

A) to stop further participation in the second pillar. In this paper, this option was not analysed, as only 24 thousand participants out of 1117 thousand (or 2.1\%) selected it.

B) to increase participation in the second pillar (by paying additional 2 per cent contribution supplemented with the state contribution of 2 per cent of average country wage).

C) To stay in the previous participation level (see Maccioni, Gudaitis, 2014). 


\section{The International Journal}

ENTREPRENEURSHIP AND SUSTAINABILITY ISSUES

ISSN 2345-0282 (online) http://jssidoi.org/jesi/

2018 Volume 6 Number 2 (December)

http://doi.org/10.9770/jesi.2018.6.2(11)

The aim of this paper is to evaluate how rational second pension pillar participants were in their decisions on selecting the accumulation rate, appropriate pension fund (investment strategy and investment risk), and changing the pension fund over the accumulation period during different stages of the economic cycle in the financial markets.

\section{Behaviour in defined contributions pension accumulation period}

Decision making on long-term investments, such as a pension has not been analysed systematically in literature. Collard (2009) indicated a widespread lack of knowledge and understanding about how people choose pension (and investment) funds. In order to fill existing knowledge gaps, the authors of this paper evaluated three key aspects of pension fund participants' behaviour in choosing pension funds for pension accumulation: the initial choice of investment strategy, attitude and appetite towards investment risk and changing (switching) the investment strategy and risk during the accumulation period.

In scientific literature, the initial investment strategy choice in pension accumulation is analysed from the perspective of behaviour economics. Bodie et al (1992) showed that labour and investment choices are intimately related. Due to this, an individual simultaneously determines the optimal levels of current consumption, labour effort, and an optimal financial investment strategy at each point in his life-cycle. This research has laid the foundations for a life-cycle funds market. The optimal asset allocation for a long-term investor has been analysed by Campbell and Viceira (2002), who argue that many households are inadequately diversified and fail to optimize their portfolios correctly. The life-cycle model was thus reconfirmed as the optimal one. Blake et al (2014) investigated pension accumulation strategies under the assumption that the member is a rational life-cycle financial planner and has an Epstein-Zin utility function. One of key findings shows that optimal investment strategy during the accumulation phase of the plan is 'stochastic life styling', with an initial high weight in equitytype investments and a gradual switch to bond-type investments as the retirement date approaches in a way that depends on the realized outcomes for the stochastic processes driving the state variables.

However, in many countries the prevailing practice of pension accumulation systems, especially with voluntary participation like in Lithuania, is based on the offering of fixed investment strategy pension funds, and it is expected that pension fund participants will be active and will change the pension fund strategy (risk) during the long-term pension accumulation period, and no life-cycle funds market exists. As the results of previously conducted research in different countries show, participants are not willing to change the initially selected investment strategy. Benartzi and Thaler (2001) came to the conclusion that a clear link exists between the menu of investment funds offered and the eventual pattern of asset holding diversification in different asset classes. Moreover, participants use naive diversification strategies that are heavily influenced by the menu offered by the pension plan. Choi et al (2002) have analysed the choices of participants in defined contribution pension funds in the US. It was concluded, that in the case of automatic enrolment, participants remain at the default asset allocation specified by the employer. Tapia and Yermo (2007) compared ten countries that have implemented investment choice in the accumulation stage of their individual account pension system. Menu design (the number and structure of investment portfolio options available during the account accumulation phase) matters enormously for the choices actually made by investors. Another key conclusion is that participants do not exercise active choice.

Attitude and appetite towards investment risk in pension accumulation is another important element, which needs to be assessed by analysing participant's behaviour in choosing a pension fund. Peggs (2000) showed that material circumstances, cultural capital, the extent and quality of pension information and habitus affect the perceptions of pension choice and pension risks. The paper concludes that the expansion of pension choice has been, in many ways, negative rather than positive. Schooley and Worden (1999) concluded, that investment in 


\section{The International Journal}

ENTREPRENEURSHIP AND SUSTAINABILITY ISSUES

ISSN 2345-0282 (online) http://jssidoi.org/jesi/

2018 Volume 6 Number 2 (December)

http://doi.org/10.9770/jesi.2018.6.2(11)

risky assets is significantly related to socioeconomic factors, attitude toward risk taking, desire to leave an estate and expectations about the adequacy of social security and pension income. Dulebohn (2002) examined the significance of demographic and attitudinal/dispositional variables on employees' risk behaviour in selecting among investment allocation options provided by defined contribution pension plans. The results identified primary causes of risky investment behaviour, including income, age, other retirement plan participation, selfefficacy, knowledge of investment principles and general risk propensity. Research results of Clark and Strauss (2008) demonstrated that pension-plan participants do not appear to understand the risks associated with different types of retirement savings and pension plans. The gender, age, and income of plan participants can give rise to distinctive risk propensities, and marital status and, in particular, whether a spouse also has a pension can also have significant consequences for household risk preferences. Jonsson et al (2017) investigated the impact of financial literacy, risk attitude, and saving motives on the attenuation of mutual fund investors' disposition bias. The results show that investors with high levels of "market knowledge" and "mutual fund knowledge" are more likely to sell shares in a fund performing below the reference point, regardless of the performance of other funds in the portfolio. Foster (2015) analysed the attitude of young people to pension savings. The results showed that pension system development needs to be accompanied by access to suitable impartial guidance, in order for people to be able to make informed choices. Lusardi and Mitchell (2017) concluded that competent planning for retirement and investing of retirement assets requires individuals to understand the risk/return relationship and risk diversification.

Changing (switching) the investment strategy and risk is a third element of the participation strategy during the pension accumulation period. The evidence shows a general trend of low levels of changing investment strategy over the accumulation period (switching the fund) by pension fund (plan) participants.

Ameriks and Zelders (2002) analysed the portfolios and portfolio choices of US households. The results show an infrequency of active portfolio allocation changes, as almost half of the sample members made no active changes to their portfolio allocations over a nine-year sample period. There is very limited data about whether or not pension funds (plan) participants make rational choices when switching the fund. The research results show that the majority of pension plan participants pay insufficient attention to their investment portfolios and do not actively manage them (see, e.g., Abel, Eberly and Panageas (2013); Bilias, Georgarakos, and Haliasos (2009); Dellavigna and Pollet (2008); and Tang, Mitchell, Mottola and Utkus (2009)). Some opposite results are provided by Betermier et al (2017). The analysis of Swedish residents shows that over the life-cycle, households progressively shift from growth to value as they become older and their balance sheets improve. Additionally, Dahlquist et al (2017) conclude that in Sweden's Premium Pension System, active investors earn higher returns and risk-adjusted returns than inactive investors. A performance decomposition analysis reveals that most outperformance by active investors is the result of active investors successfully timing mutual funds and asset classes. It might be linked to higher financial literacy of a society (Lusardi and Mitchell, 2011).

\section{Methodology and data}

The authors analysed depersonalized data of all 1.2 million pension fund participants, provided by State Social Insurance Fund Board (Sodra), and the behaviour of pension fund participants during a period of 13 years. The analysis covers a period from the beginning of the reform in 2004 Q2 till 2016 Q3. The data sample allowed to identify the date when a citizen started to participate in the system, when they changed the fund (if they did at all), which investment strategy was chosen, and what participation level (contribution level) was selected. Additionally, the data sample allowed to identify sociodemographic factors, such as the age, gender, contribution size, and taxable income (salary) of the participant.

Firstly, the authors analysed the behaviour of participants when selecting a pension fund (investment strategy and investment risk). As it was described earlier, second pillar pension funds in Lithuania are divided into four groups 
according to their investment strategy (investment risk). It is expected, that young-age participants would follow a life-cycle investment strategy and select pension funds with higher investment risk (e.g. a pure equity pension fund) in the beginning of the accumulation period, and closer to retirement age they would gradually decrease investment risk by changing the pension fund to a more conservative investment strategy with a smaller proportion of equities. Due to data limitations, the authors made an assumption about how pension fund participants would select a pension funds investment strategy according to age and how pension fund participants would gradually change the pension fund - decreasing investment risk by selecting a pension fund from another pension fund category (Table 1).

Table 1. Participant age and suitable pension fund category

\begin{tabular}{|l|c|c|c|c|}
\cline { 2 - 5 } \multicolumn{1}{c|}{} & \multicolumn{4}{c|}{ Age groups } \\
\hline Pension fund category & $<44$ & $45-53$ & $54-57$ & $58>$ \\
\hline Conservative (0\% equities) & & & $\mathrm{X}$ & \\
\hline up to $30 \%$ equities & & & & \\
\hline up to $70 \%$ equities & & $\mathrm{X}$ & & \\
\hline up to $100 \%$ equities & $\mathrm{X}$ & & & \\
\hline
\end{tabular}

Source: authors' assumptions according to the data of The Bank of Lithuania (2016)

Additionally, the authors analysed which participation (contribution) level was chosen by participants during the 2013 reform (Option B or C, as described in the introduction). The authors analysed the selected participation (contribution) level by received monthly income. Participants were classified into 4 income groups by received salary size per month:

1. Up to minimum salary.

2. Above minimum salary, up to the country-average salary.

3. Up to 3 times the country-average salary.

4. More than 3 times the country average salary.

The authors made the assumption that for participants whose monthly income was below the country average salary (in 2013, the average gross country salary was EUR 646.3 and the minimum monthly wage was EUR 289.6), it was the most rational to choose option B rather than C, due to the fact that in such a situation the incentive from the Government would be higher compared to the participants' additional contributions to the second pillar pension fund.

Secondly, the authors analysed how active second pillar pension fund participants were in changing pension funds during accumulation. It was analysed how many times a pension fund participant changed pension funds, or if they have not changed funds at all, staying with the initial choice. Additionally, the authors have deeper investigated the behaviour of those participants who have changed the pension fund at least once, and tried to determine any special triggers or reasons for such behaviour over the accumulation period, specifically, triggers that would constantly reoccur and influence the peaks of pension fund changes.

Thirdly, the authors have analysed how rational were second pension pillar participants in changing pension funds during the peaks and bottoms in stock markets. We have selected four periods ( 2 peaks and 2 bottoms) in equity markets, based on the historical data of NYSE100 and EuroStoxx 50 indexes (Fig. 1). In each case, we selected a 4-month period ( 2 months before and 2 months after the peak or bottom) and analysed if pension fund participants have increased or decreased investment risk by switching the fund. 


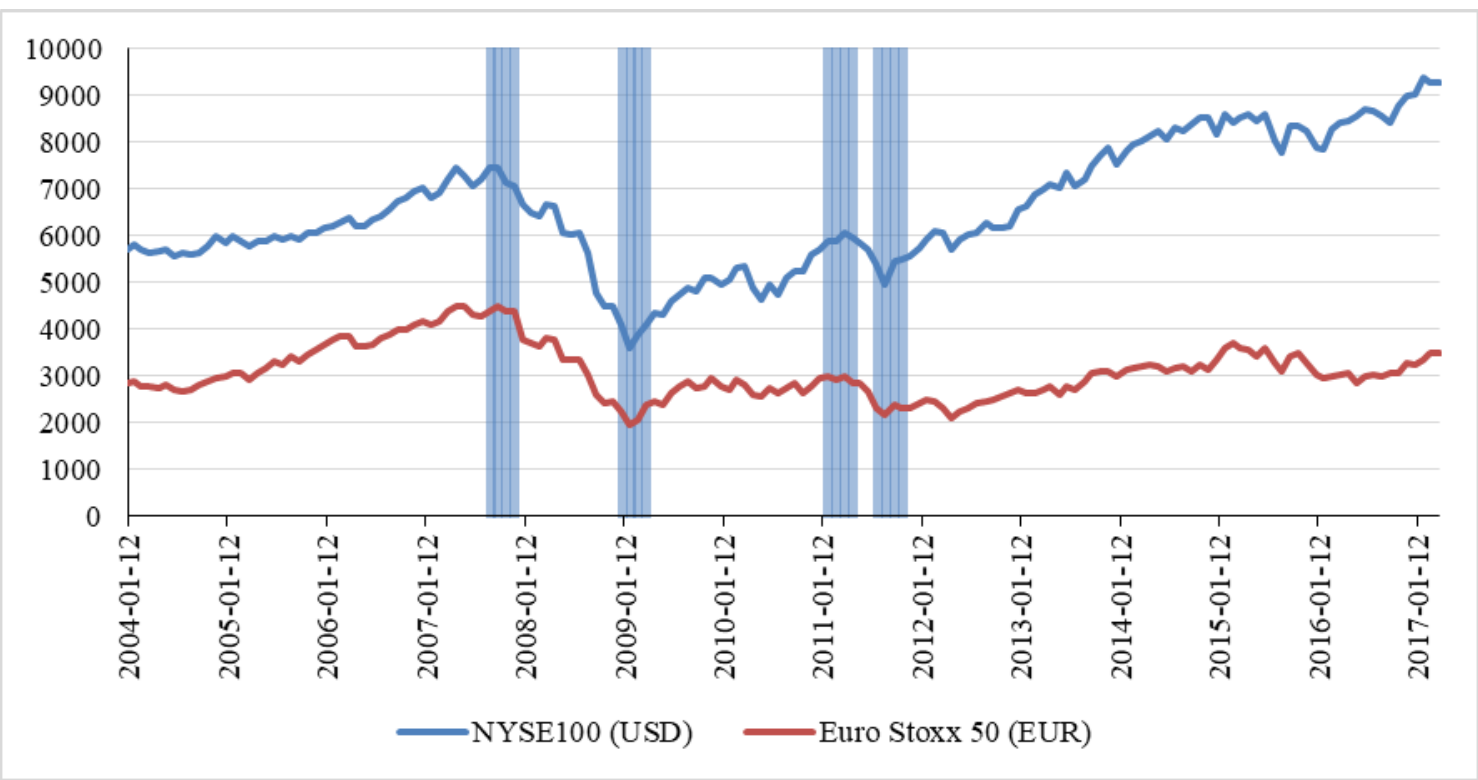

Figure 1. The close price of NYSE100 and Euro Stoxx 50 indexes and selected periods of peaks and bottoms Source: "Yahoo finance" (09/04/2017)

The authors made the following assumptions:

a) In case of a peak period in stock markets, second pension pillar participants shall change pension funds by switching from the fund with the higher proportion of equities to the fund which has lower proportion of equities. If a participant changed the pension fund to a fund in the same category or if the participant changed a pension fund with a higher proportion of equities, then the authors stated that the participant made an irrational decision.

b) In the case of a bottom period in stock markets, second pension pillar participants shall change pension funds, by switching from the fund with the lower proportion of equities to the fund with the higher proportion of equities. If a participant changed the pension fund to a fund in the same category or changed a pension fund with a lower proportion of equities, then the authors stated that the participant made an irrational decision.

\section{Results}

Firstly, the analysis of pension fund participants' behaviour on selecting a pension fund (investment strategy and investment risk) showed, (Fig. 2, 3, 4), that, on average, 65.5 per cent of the participants selected an inappropriate investment strategy according to the life-cycle investment strategy. The largest discrepancies were observed among the youngest participants (74.5\% selected an inappropriate, too conservative investment strategy) and most senior pension fund participants (56.1\% selected an appropriate, too risky investment strategy). Due to the inappropriate choice of investment strategy and the level of investment risk, the youngest pension fund participants risk to accumulate insufficient assets in the second pillar pension funds due to a lower investment risk (potentially lower investment return) chosen in the beginning of the accumulation period. Meanwhile, senior pension fund participants risk to lose a part of their accumulated capital due to the a high investment risk chosen and potential significant market fluctuations at the end the of accumulation period (before the start of retirement). 


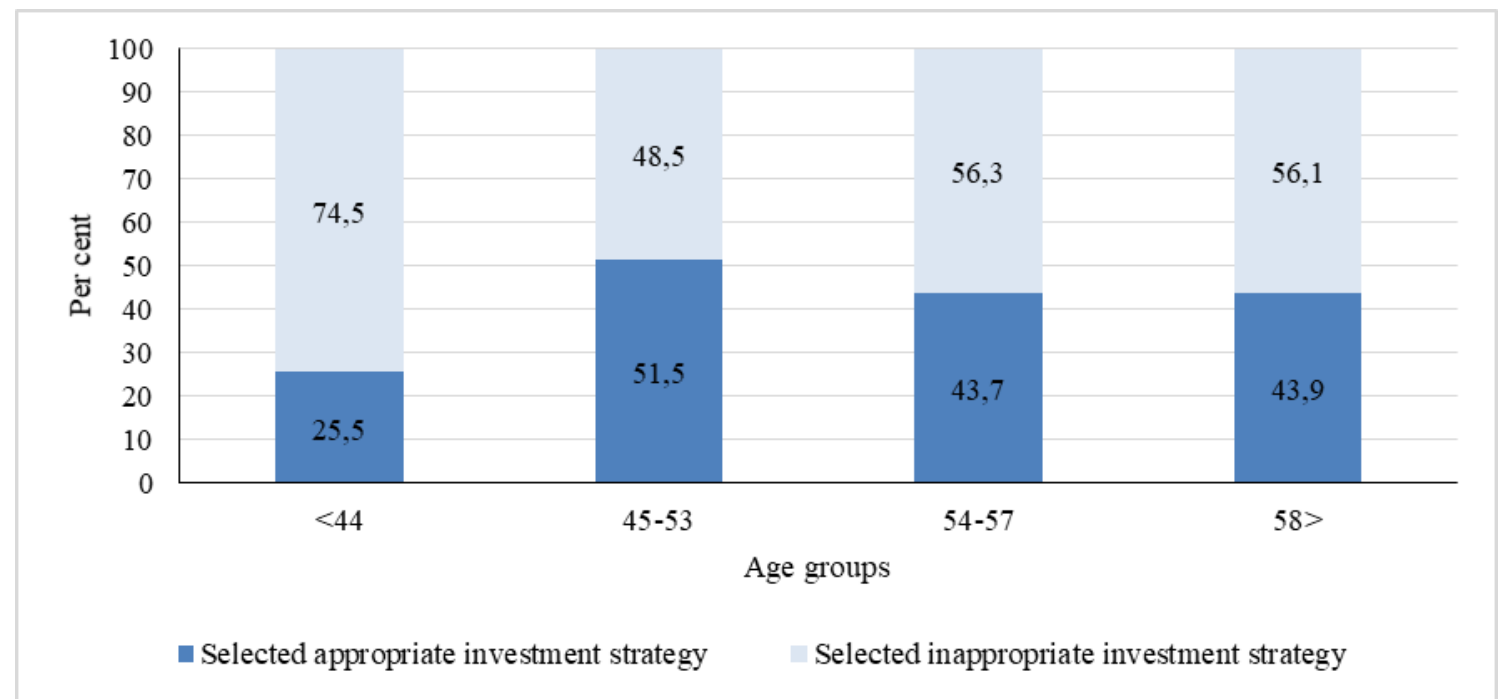

Figure 2. Selection of appropriate investment strategy according to second pillar participants' age

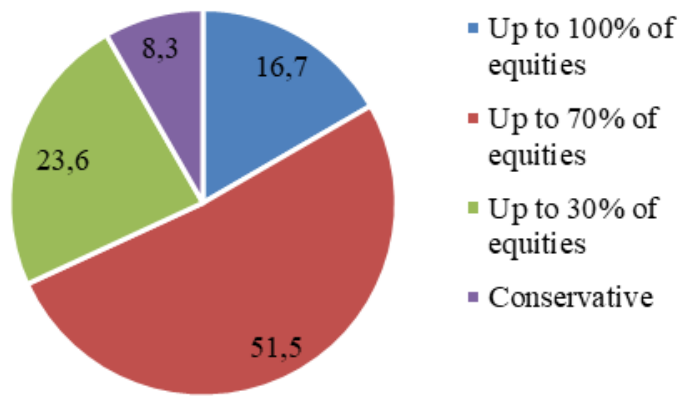

Figure 3. Second pillar participants by selected fund category at the end of $2016 \mathrm{Q} 3$, per cent

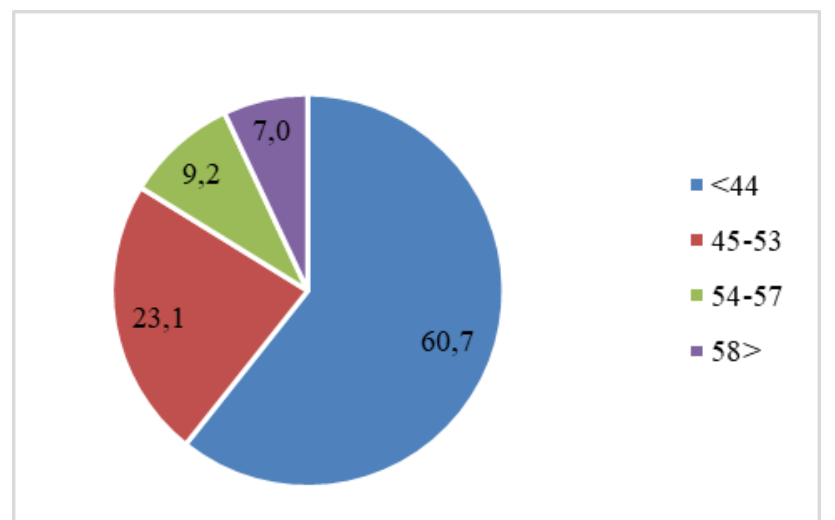

Figure 4. Second pillar participants by age groups at the end of 2016 Q3, per cent

An analysis of the participation (contribution) level, which was chosen by participants during the 2013 reform showed (Fig. 5), that approx. 39.3 per cent (34.8 per cent in EUR 290 and less range and 42.0 per cent in 290-646 EUR range) of all participants who received lower than average monthly income have selected to increase their contributions and to get an incentive from the Government. Comparably, only 31.7 per cent of the participants who have received higher than three times the country average salary have selected this option. However, more than half of all the participants selected to stay with the minimal contribution level and did not increase it. Additionally, an analysis of the participation (contribution) level - which was chosen by participants during the 2013 reform - showed (Fig. 5), that approx. 33 per cent of all participants who received lower than average monthly income have selected to increase their contributions and to get an incentive from the Government. 


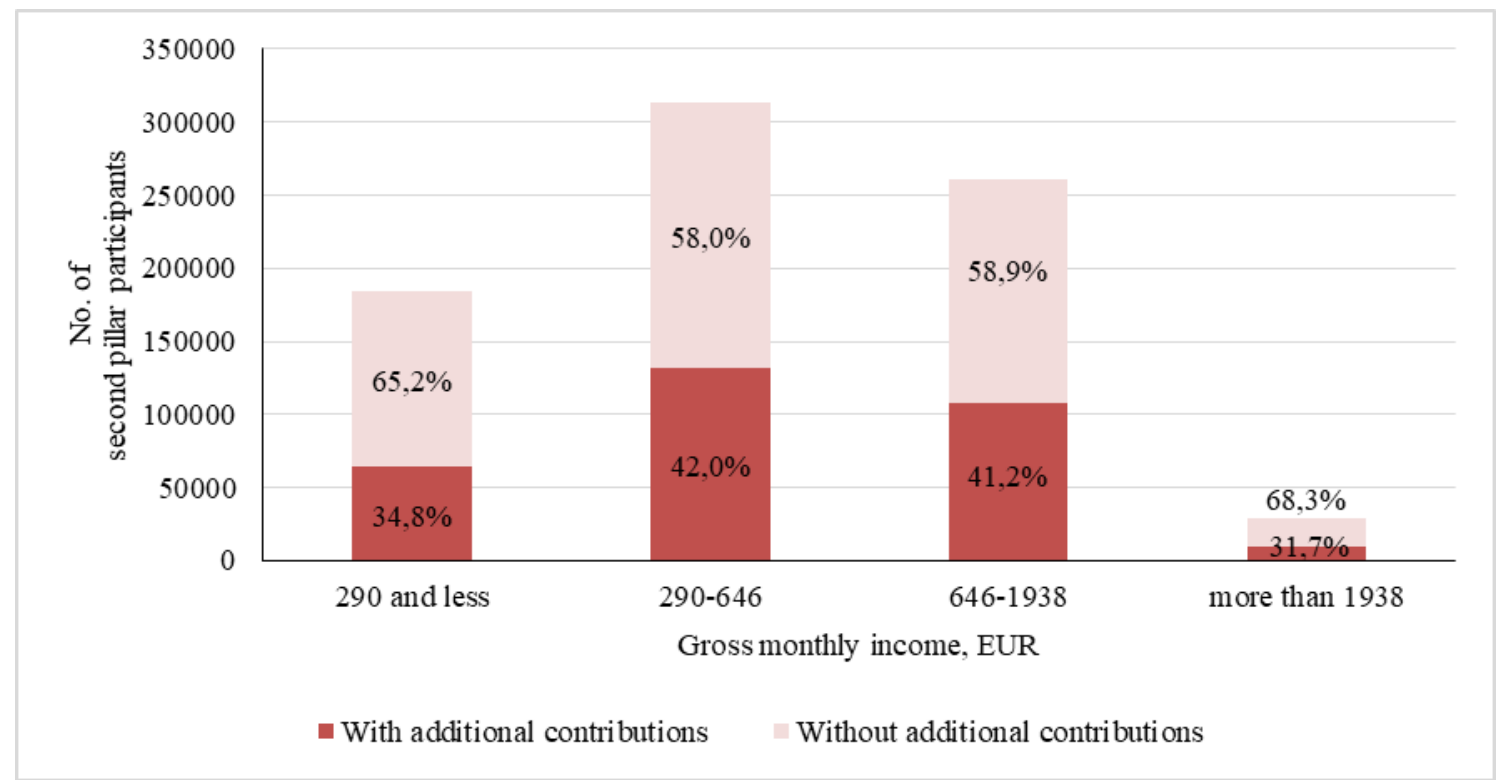

Figure 5. Second pillar participants who started to participate before the year 2013, by monthly income (in the year 2013) and participation level at the end of 2016 Q3

Secondly, the analysis of pension funds participants' activeness in changing the fund showed that participants are very passive and do not change the investment strategy (investment risk) during the accumulation period. During the analysed period (13 years), $75 \%$ of participants did not change their initial selection and accumulated in the same pension fund from the beginning of accumulation. Additionally, $20 \%$ of participants changed their pension fund only once (Table 2).

Table 2. No of Second pillar pension fund selections during the accumulation period (2004-2016 Q3).

\begin{tabular}{|c|c|}
\hline $\begin{array}{c}\text { No of pension fund } \\
\text { selections }\end{array}$ & Participants \\
\hline 1 & 931,764 \\
\hline 2 & 249,749 \\
\hline 3 & 45,987 \\
\hline 4 & 8,123 \\
\hline 5 & 1,966 \\
\hline $6-10$ & 1,143 \\
\hline $11-20$ & 148 \\
\hline $21+$ & 74 \\
\hline Total & $\mathbf{1 , 2 3 8 , 9 5 4}$ \\
\hline
\end{tabular}

Additionally, the authors have deeper investigated the behaviour of participants who have changed the pension fund at least once ( 2 and more selections) and tried to determine triggers or reasons over the accumulation period, which constantly recurred and influenced peaks of pension fund changes. A monthly split of participants' decisions to switch the fund is presented in Fig 6. The peaks of changes were observed in the beginning of each calendar year. According to the legal requirements, pension accumulation companies shall send an annual second pillar pension account statement to the participants. The authors made a conclusion, that after receiving the annual 
statement, pension fund participants switched the fund - or even pension accumulation company - more actively.

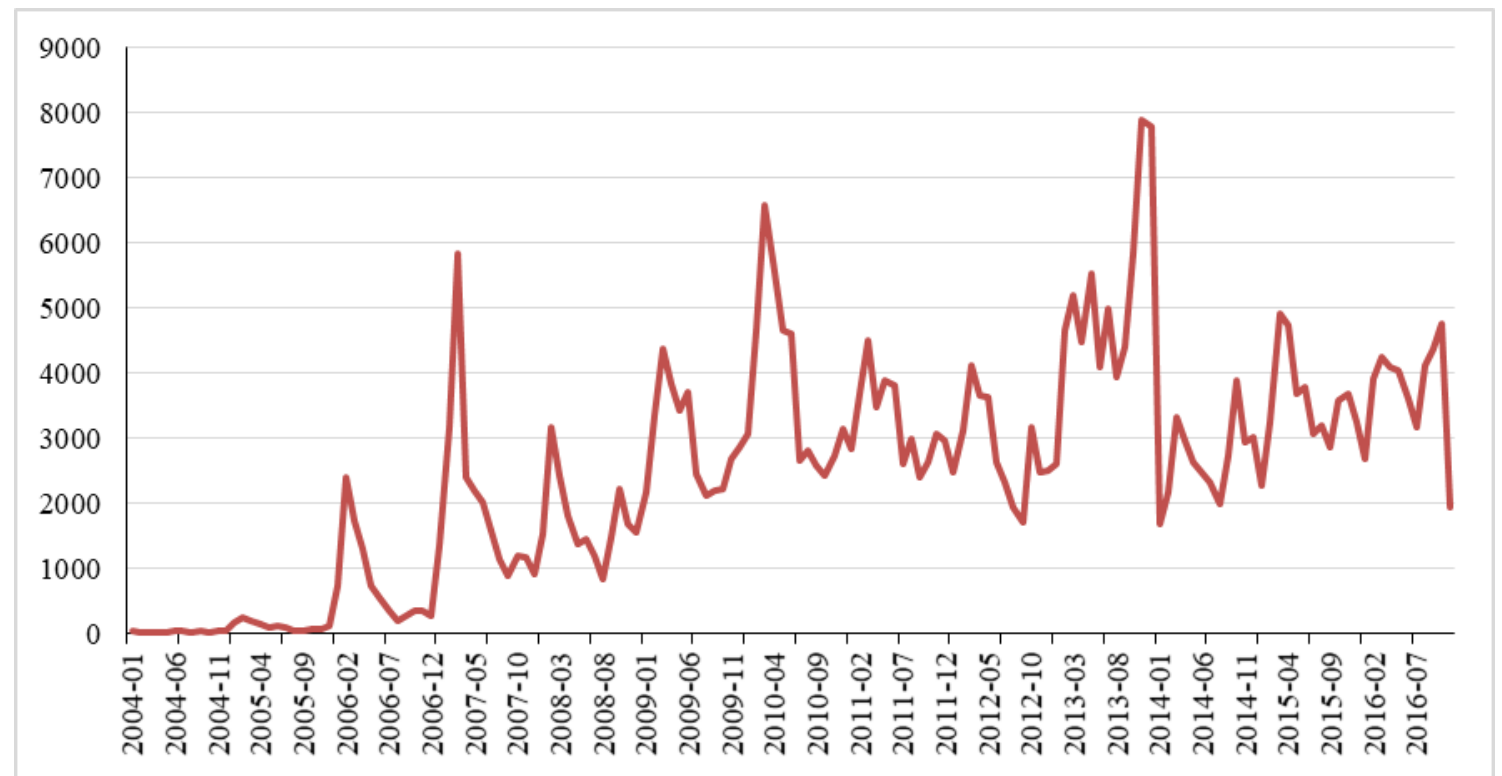

Figure 6. The number of participants' decisions to change Second pillar pension fund per month

Thirdly, the analysis of pension funds participants' behaviour in the case of equity price peaks (at the highest point of the equities' value) and bottoms (at the lowest point of the equities' value) showed that for both cases the majority of participants behave irrationally by changing the pension fund (investment risk and investment strategy).

In case of both analysed peak periods (2007 Sep-Dec and 2011 Feb-May) in equities markets, the majority of second pension pillar participants in all analysed age groups (Fig. 7 and Fig. 8) changed pension funds by switching from the fund with a lower proportion of equities to the fund with a higher proportion of equities or switched to a pension fund with the same investment risk.

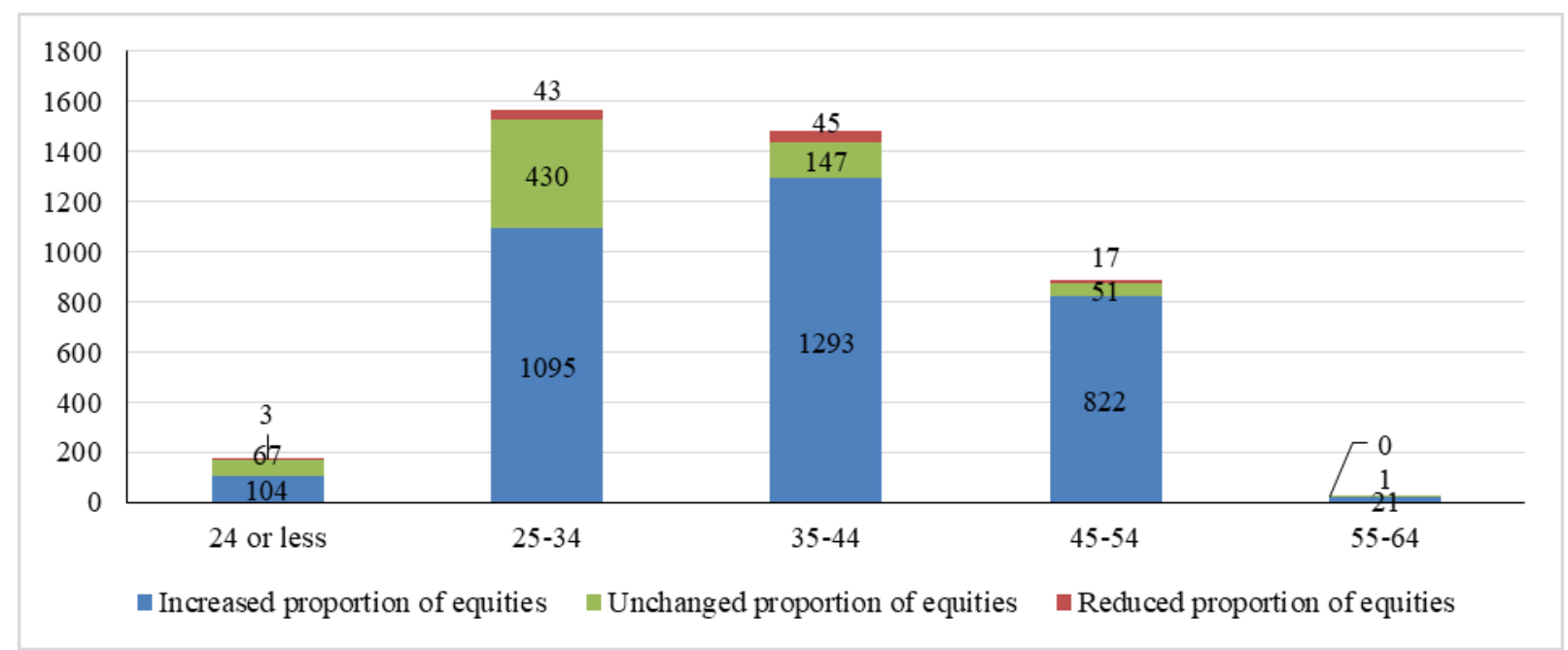

Figure 7. The changes of pension fund in peak period in equities markets according to participants' age (2007 Sep-Dec) 


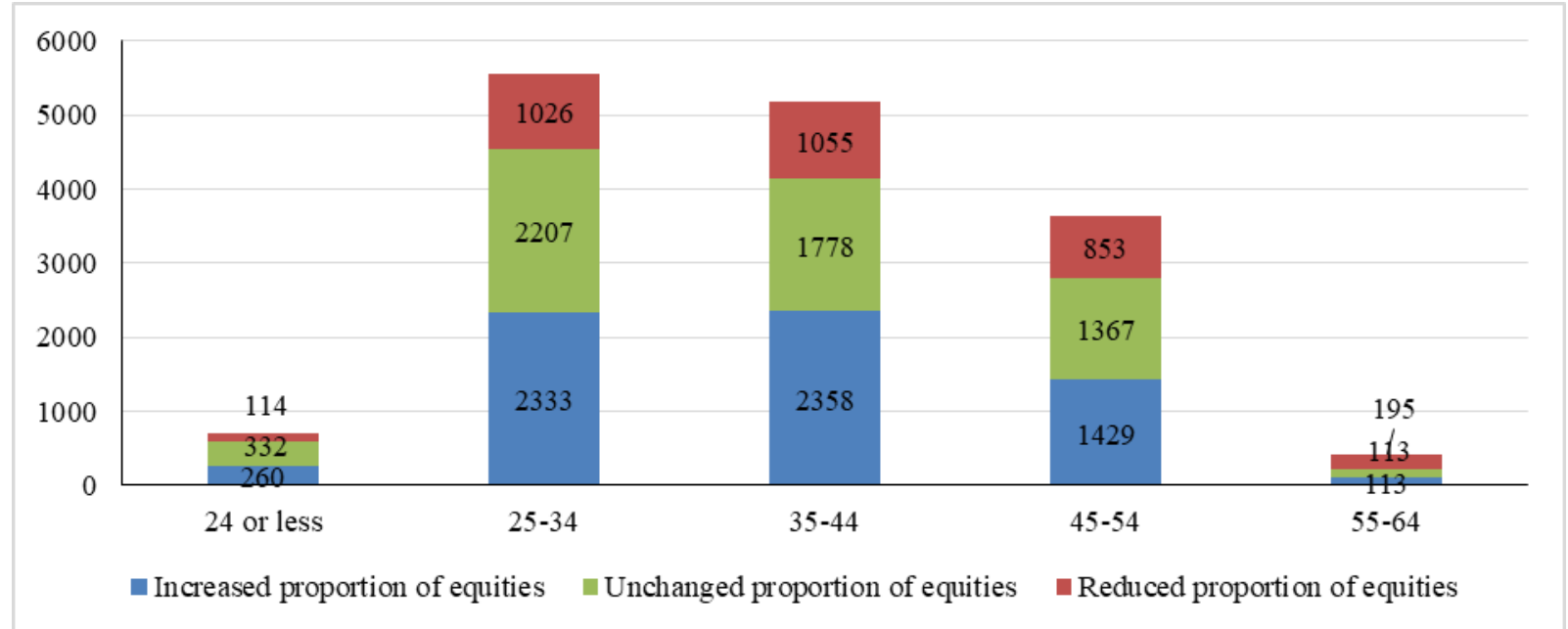

Figure 8. The changes of pension fund in peak period in equities markets according participants' age (2011 Feb-May)

The same results were observed in all analysed income groups (Fig. 9 and Fig. 10). The majority of participants in all income groups changed pension funds by switching from the fund which had a lower proportion of equities to the fund which had a higher proportion of equities or changed to pension fund with the same investment risk.

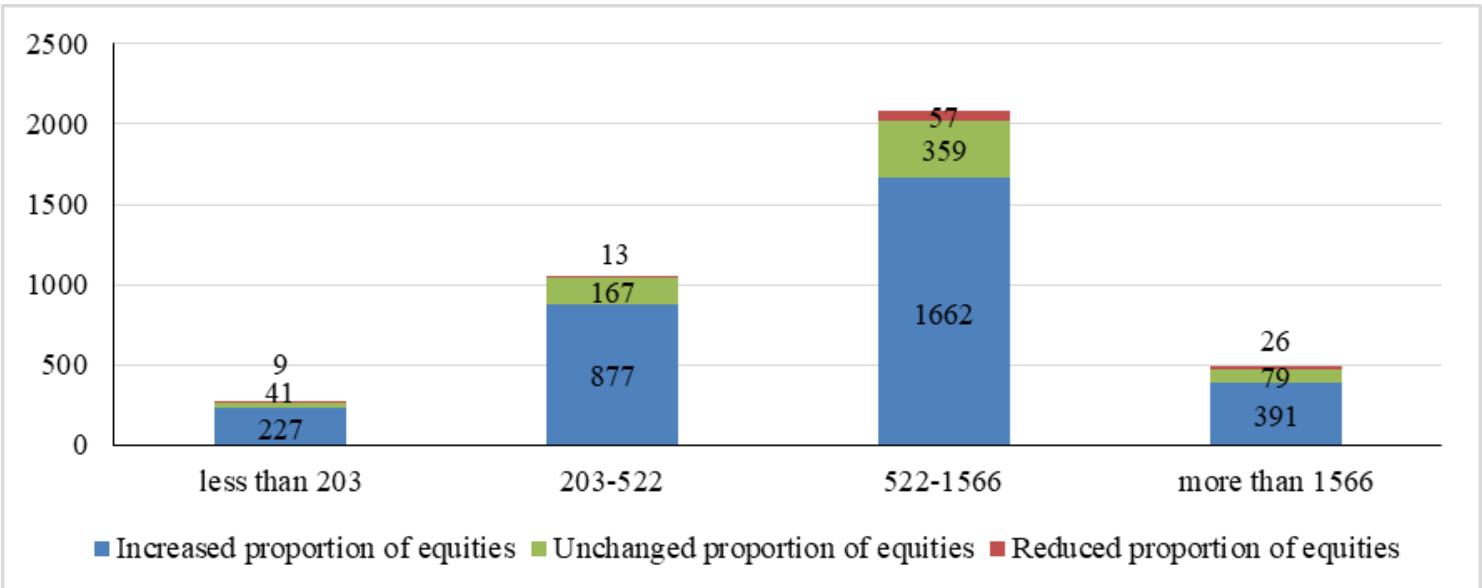

Figure 9. The changes of pension funds in peak periods in equities markets according to participants' income (2007 Sep-Dec) 


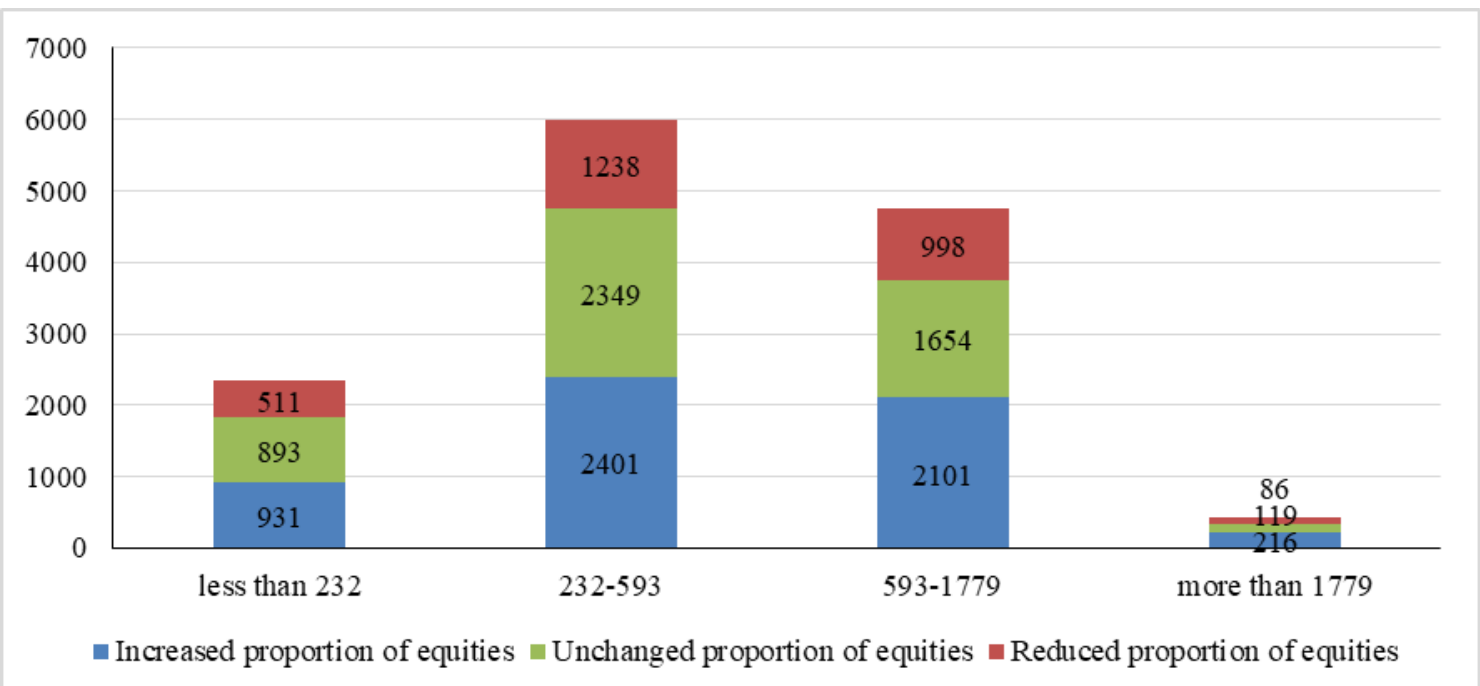

Figure 10. The changes of pension funds in peak periods in equities markets according to participants' income (2011 Feb-May)

In case of both analysed bottom periods (2009 Jan-Apr and 2011 Aug-Nov) in equities markets, the majority of second pension pillar participants in all analysed age groups (Fig. 11 and Fig. 12) changed pension funds by switching from the fund with the higher proportion of equities to the fund with the lower proportion of equities or have changed to pension funds with the same investment risk.

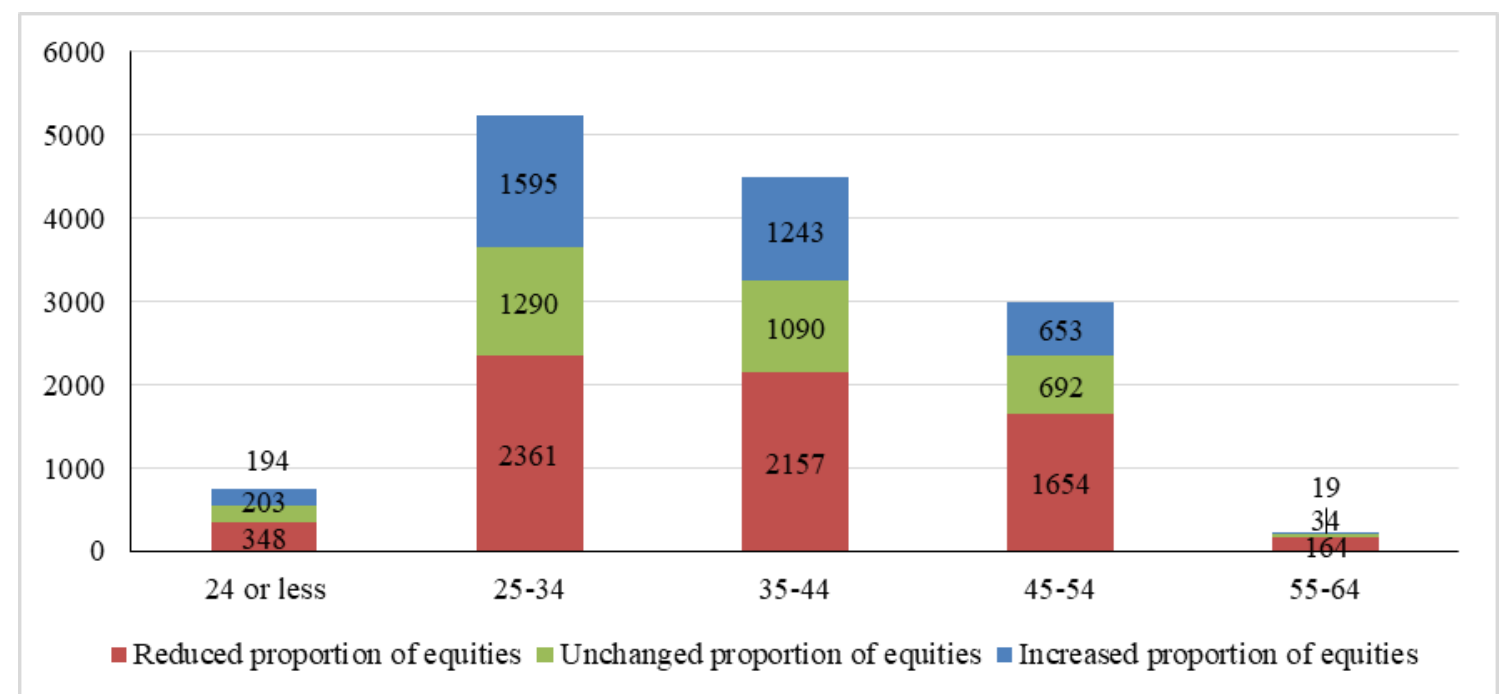

Figure 11. The changes of pension funds in bottom period in equities markets according to participants' age (2009 Jan-Apr) 


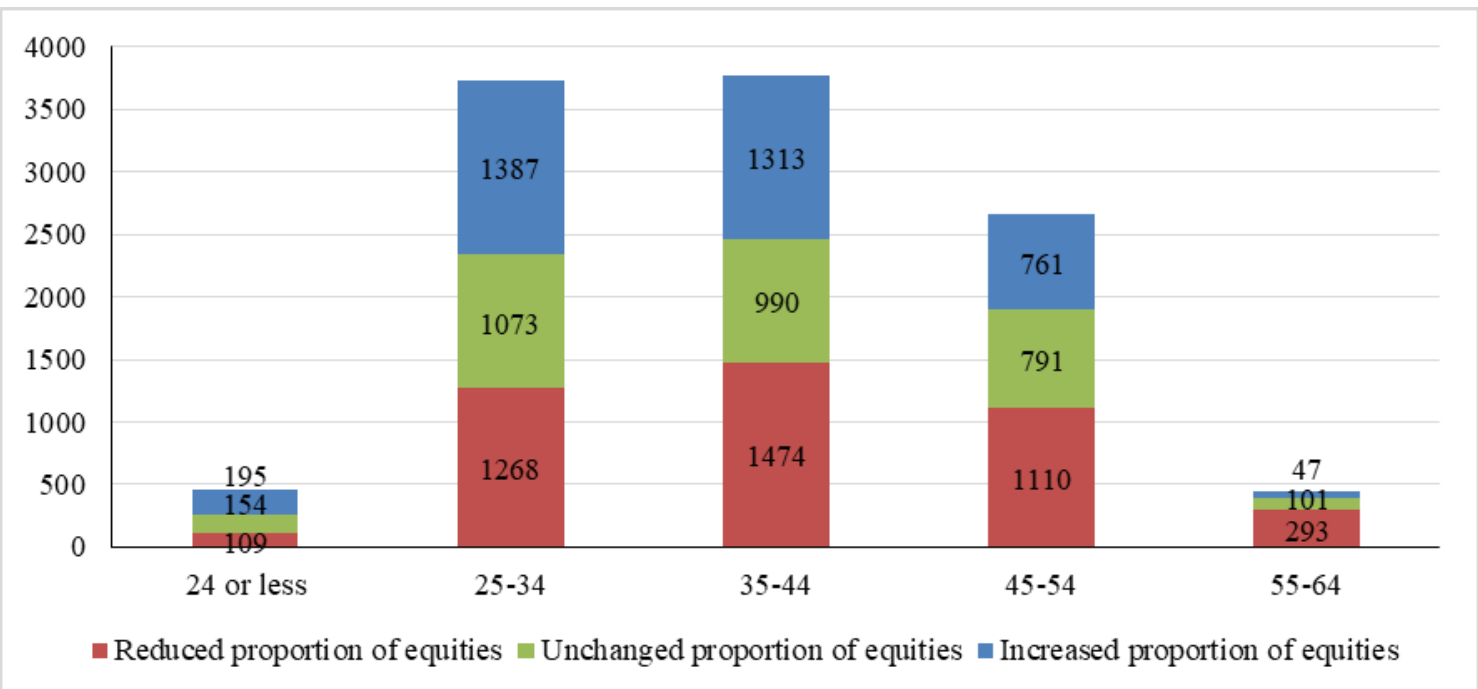

Figure 12. The changes of pension funds in bottom period in equities markets according to participants' age (2011 Aug-Nov)

The same results were observed in all analysed income groups (Fig. 13 and Fig. 14). The majority of participants in all income groups have changed pension funds by switching from the fund with a higher proportion of equities to a fund with a lower proportion of equities, or have changed to a pension fund with the same investment risk.

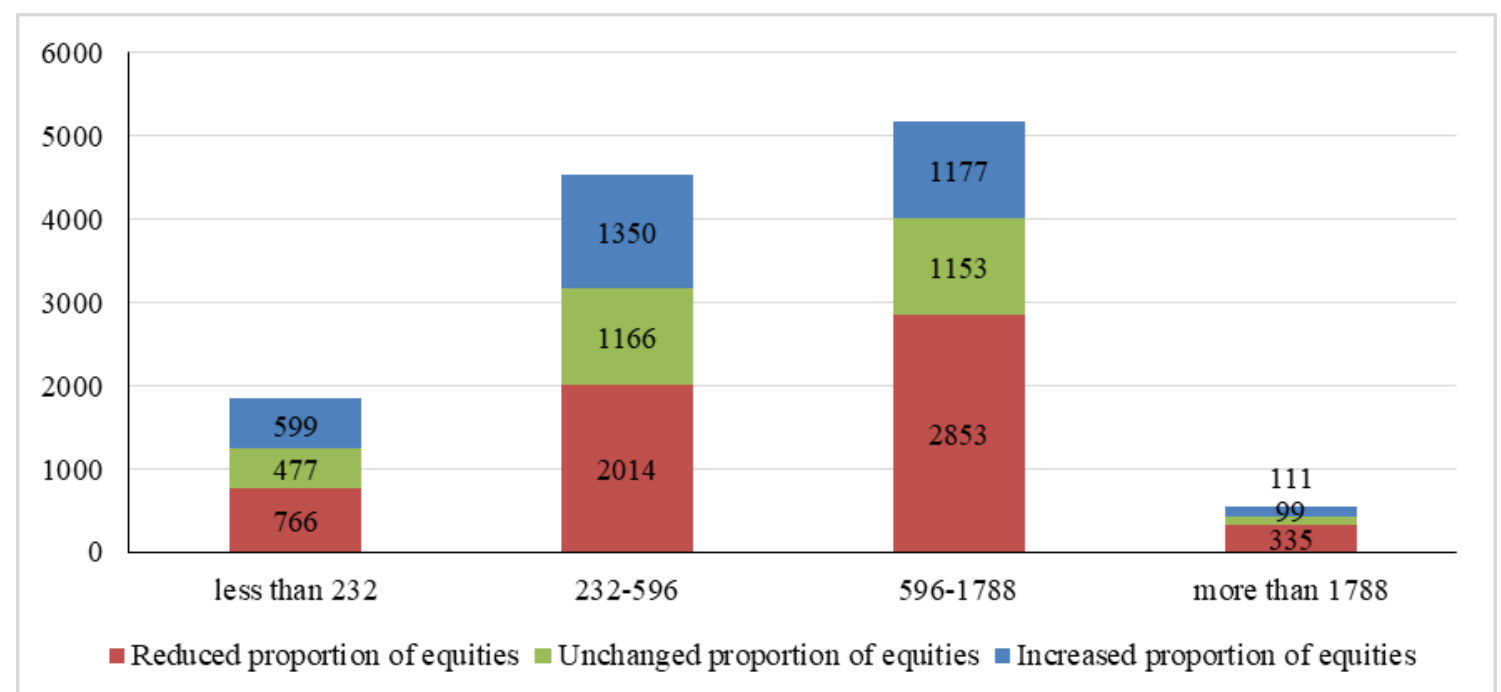

Figure 13. The changes of pension funds in bottom period in equities markets according to participants' income (2009 Jan-Apr). 


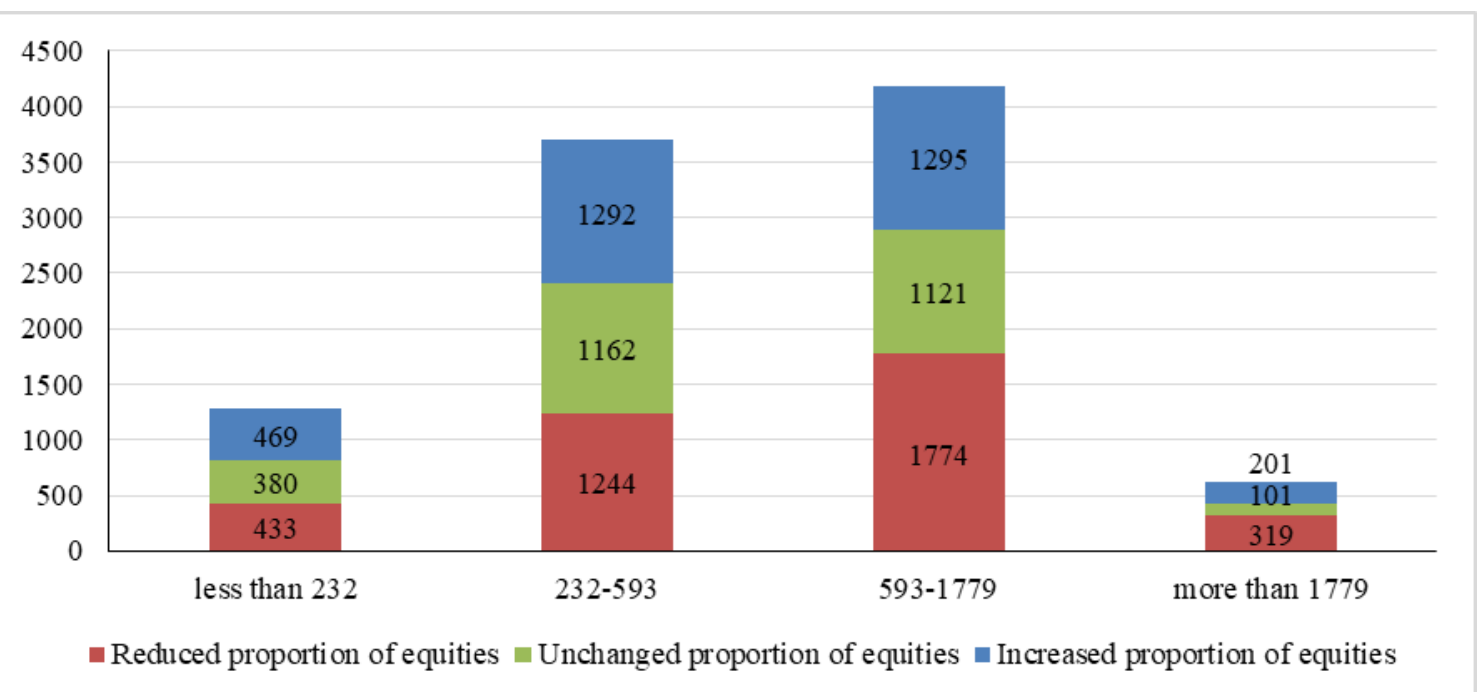

Figure 14. The changes of pension funds in bottom period in equities markets according to participants' income (2011 Aug-Nov).

\section{Conclusions}

The assessment of the database of all second pillar pension fund participants' behaviour in Lithuania from the establishment of the second pension pillar in 2004 till the 2016 Q3 showed that participants make irrational decisions in different stages of accumulation. This study provided evidence that second pillar pension participants are irrational in selecting the accumulation rate, appropriate pension fund (investment strategy and investment risk), and changing the pension fund over the accumulation period during different stages of the economic cycle in the financial markets.

The analysis of second pillar pension participants' data provided evidence that on average 65.5 per cent of the participants have selected an inappropriate investment risk and investment strategy according to the life-cycle investment strategy. Due to the inappropriate choice of investment strategy and the level of investment risk, the youngest pension fund participants risk accumulating insufficient assets in the second pillar pension funds due to the lower investment risk chosen in the beginning of the accumulation period. Moreover, senior pension fund participants risk losing a part of their accumulated capital due to the high investment risk chosen and potential significant market fluctuations at the end of the accumulation period (before the start of retirement). The analysis also showed that the majority of participants are inactive and do not change the investment strategy over accumulation period. During the analysed period (13 years), $75 \%$ of participants did not change their initial selection and accumulated in the same pension fund from the beginning of accumulation. Finally, research showed, that the majority of participants who made the decision to change the pension fund (investment strategy and investment risk) during equity price peaks (at the highest point of the equities' value) and bottom (at the lowest point of the equities' value) in both cases behaved irrationally by changing the pension fund. In case of both analysed peak periods (2007 Sep-Dec and 2011 Feb-May) in equities markets, the majority of second pension pillar participants changed pension funds by switching from the fund with the lower proportion of equities to the fund with the higher proportion of equities, or have changed to pension fund with the same investment risk. In case of both analysed bottom periods (2009 Jan-Apr and 2011 Aug-Nov) in equities markets, participants acted in an opposite manner. 
The International Journal

ENTREPRENEURSHIP AND SUSTAINABILITY ISSUES

ISSN 2345-0282 (online) http://jssidoi.org/jesi/

2018 Volume 6 Number 2 (December)

http://doi.org/10.9770/jesi.2018.6.2(11)

An analysis of the participation (contribution) level - which was chosen by participants during the 2013 reform showed, that more than half of all the participants selected to stay at the minimal contribution level and have not increased it. This might potentially lead to low accumulated amounts for the retirement.

Additionally, research results provide important insights for public policy, with the possibility of including the preferences in regulations with the aim of benefiting pension fund participants in a long term perspective. Overall, the findings have important implications for introducing life-cycle investment strategies as a default option in the second pension pillar. Stricter rules are needed in terms of pension fund investment strategies and their linkage to a fund participant's age in order to increase compatibility between investment strategies and the investment risk of pension funds on the one hand, and the needs of pension system participants over their entire accumulation period on the other hand.

However, there are several limitations to the research. Firstly, the authors have analysed only data about the second pillar pension and did not analyse data about the third pillar pension, because it was not available. On the other hand, due to low participation levels in the third pension pillar, the outcome of the analysis would not significantly influence the achieved results. In order to make more critical conclusions, analysis of data from all three pension pillars would be necessary. Secondly, pension funds are long-term products, thus a 13-year period of analysis is relatively short compared with the whole accumulation cycle of 30-45 years.

Decision making on long-term investments, such as a pension has not been analysed systematically in literature. Future research of second pillar pension participants' choices in Lithuania should be compared with the behaviour of second pillar pension participants in similar markets, for example, those of the other Baltic countries and other Central European countries in order to make a more comprehensive comparison of factors that influence the behaviour of second pillar pension participants. Additionally, similar research should be repeated after several years, when pension funds will have been operating for 20 years or more.

\section{Funding}

This work was supported by the Research Council of Lithuania under Grant MIP-15204. The research has received funding from Research Council of Lithuania on research project agreement No MIP-012/2015.

\section{References}

Abel, A.; Eberly, J. C.; Panageas, S. 2013. Optimal Inattention to the Stock Market with Information Costs and Transaction Costs, Econometrica 81: 1455-1481. https://doi:10.3982/ECTA7624

Ameriks, J; Zeldes, S. P. 2002. How do household portfolio shares vary with age? TIAA-CREF Working Paper 112(2).

Bank of Lithuania. 2016. [online], [cited 15 November 2017]. Available from Internet: http://www.lb.lt/en/lb-statistics.

Benartzi, S.; Thaler, R. H. 2001. Naive diversification strategies in defined contribution saving plans, American Economic Review 91(1): 79-98.

Betermier, S.; Calvet, L. E.; Sodini, P. 2017. Who Are the Value and Growth Investors? The Journal of Finance 72: 5-46. https://doi:10.1111/jofi.12473

Blake, D.; Wright, I.D.; Zhang, Y. 2014. Age-dependent investing: optimal funding and investment strategies in defined contribution pension plans when members are rational life cycle financial planners, J. Econom. Dynam. Control 38: 105-124. https://doi.org/10.1016/j.jedc.2013.11.001 


\section{The International Journal}

ENTREPRENEURSHIP AND SUSTAINABILITY ISSUES

ISSN 2345-0282 (online) http://jssidoi.org/jesi/

2018 Volume 6 Number 2 (December)

http://doi.org/10.9770/jesi.2018.6.2(11)

Bodie, Z.; Merton R. C.; Samuelson W. 1992. Labor Supply Flexibility and Portfolio Choice in a Life-Cycle Model, Journal of Economic Dynamics and Control 16(3-4): 427-449.

Campbell, J.Y.; Viceira L.M. 2002. Strategic Asset Allocation: Portfolio Choice for Long-Term Investors. Oxford University Press.

Choi, James J.; Laibson, D.; Madrian, B. C.; Metrick, A. 2002. Defined Contribution Pensions: Plan Rules, Participant Choices, and the Path of Least Resistance. Tax Policy and the Economy 16: 67-113. https://doi.org/10.1086/654750

Clark, G.; Strauss, K. 2008. Individual pension-related risk propensities: the effect of socio-demographic characteristics and spousal entitlement on risk attitudes, Ageing and Society 28(6): 847-874.

Collard, S. 2009. Individual Investment Behaviour: A Brief Review of Research. Personal Accounts Delivery Authority.

Dahlquist, M.; Martinez, J. V.; Söderlind, P.2017. Individual Investor Activity and Performance, The Review of Financial Studies 30(3): 866-899. https://doi.org/10.1093/rfs/hhw093

Dellavigna S.; Pollet J. 2009. Investor Inattention and Friday Earnings Announcements, Journal of Finance 64: 709-749. https://10.1111/j.1540-6261.2009.01447.x

Dulebohn, J. H. 2002. An Investigation of the Determinants of Investment Risk Behavior in Employer-Sponsored Retirement Plans, Journal of Management 28(1): 3-26. https://doi.org/10.1177/014920630202800102

Égert, B. 2012. The impact of changes in second pension pillars on public finances in Central and Eastern Europe. OECD Economics Department Working Papers, No. 942. OECD Publishing, Paris.

Foster, L. 2017. Young People and Attitudes towards Pension Planning, Social Policy and Society 16(1): 65-80. https://doi:10.1017/S1474746415000627

Jonsson, S.; Söderberg, I. L.; Wilhelmsson, M. 2017. An investigation of the impact of financial literacy, risk attitude, and saving motives on the attenuation of mutual fund investors' disposition bias, Managerial Finance 43(3): 282-298. https://doi.org/10.1108/MF-102015-0269

Lusardi, A.; Mitchel O. S. 2011. Financial Literacy and Planning: Implications for Retirement Wellbeing, NBER WP17078. https://doi:10.3386/w17078

Lusardi, A.; Mitchell, O. S. 2017. How Ordinary Consumers Make Complex Economic Decisions: Financial Literacy and Retirement Readiness, Quarterly Journal of Finance 07:3. https://doi.org/10.1142/S2010139217500082

Maccioni, F. A.; Gudaitis, T. 2014. Contribution options and individual returns after the second pillar pension reform in Lithuania, Transformations in Business and Economics 13, 2B(32B): 591-603.

Mitchell, O. S.; Mottola, G. R.; Utkus, S. P.; Yamaguchi. T. 2009. Default, Framing and Spillover Effects: The Case of Life Cycle Funds in 401(k) Plans, NBER WP15108. https://doi:10.3386/w15108

Peggs K. 2000. Which Pension?: Women, Risk and Pension Choice, The Sociological Review 48(3): 349-364. https://doi.org/10.1111/1467-954X.00220

Schooley, D. K.; Worden, D. D. 1999. Investors' asset allocations vs. life-cycle funds, Financial Analysts Journal 55(5): 37-43.

Tapia, W.; Yermo J. 2007. Implications of Behavioural Economics for Mandatory Individual Account Pension Systems. OECD Working Papers on Insurance and Private Pensions, No. 11, OECD Publishing. https://doi:10.1787/103002825851

Volskis, E. 2012. Reforms of Baltic States pension systems: challenges and benefits [online], [cited 05 December 2017]. Available from Internet: www.ebrd.com/downloads/news/pensionsystem.pdf 
The International Journal

ENTREPRENEURSHIP AND SUSTAINABILITY ISSUES

ISSN 2345-0282 (online) http://jssidoi.org/jesi/

2018 Volume 6 Number 2 (December)

http://doi.org/10.9770/jesi.2018.6.2(11)

Teodoras MEDAISKIS is a Professor in Economics at The Faculty of Economics of Vilnius University. He is a recognized international expert in social security system, social protection, and pension insurance areas. His research interests are social security and insurance, pension reforms, and pension systems. Prior to entering the academia, he gained practical experience working in public sector.

ORCID ID: https://orcid.org/0000-0001-6258-1056

Tadas GUDAITIS is an Associate Professor in Economics at Vilnius University. He is also the Director of the International Corporate Finance Master Program at Vilnius University Business School. His research interests are: pension reforms, pension funds, financial literacy, and personal finance management. In parallel with academia, he works in the financial sector.

ORCID ID: https://orcid.org/0000-0002-2275-1388

Jaroslav MEČKOVSKI is a Master of Economics of Vilnius University. He is currently working as research assistant at Vilnius University. His research interests are: pension reforms, pension funds, and investment strategies. In parallel with the academia, he works in public sector as a statistician in Statistics Lithuania.

ORCID ID: https://orcid.org/0000-0001-5836-0189

Register for an ORCID ID:

https://orcid.org/register

Copyright (C) 2018 by author(s) and VsI Entrepreneurship and Sustainability Center

This work is licensed under the Creative Commons Attribution International License (CC BY).

http://creativecommons.org/licenses/by/4.0/

(c) (1) Open Access 